\title{
再ビ痘瘡 微生物學的診㫁二就
}

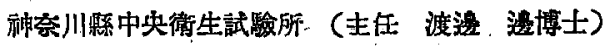 \\ 星野貫 \\ Kwan Hoshino
}

和

田保之

Yasujuki Wada

（昭和15年 2 月 12 日受付）

\section{【内容 抄 䟿】}

2例，造寻患者，Pustelinhalt $ァ$ 以テ， Elementarkörperchen, Paulsches Pliânomen, Guain-

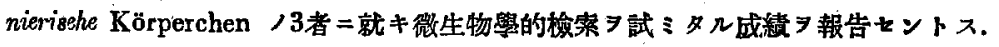

目次

緒 蓄

第 1 章 榆查事項前二检查材料

第 1 政，檢查事項

第 2 艒 檢查材料

\section{第 2 章 检查成溸}

絓 諭

引用書

附圆解筑

\section{緒」，言}

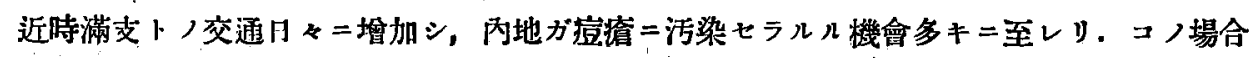

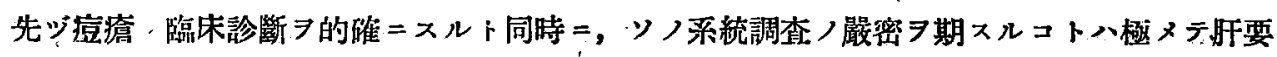

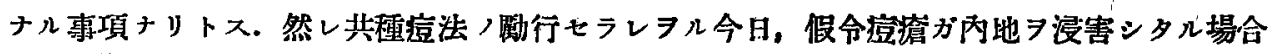
! 雖モ, 隐床上定型的ナル症例 7 見ルコトハ極メテ稀有ニシテ, 多クノモノ八假㢄二近似

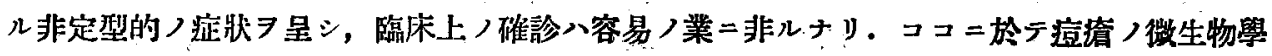
的診斷 7 可急的速ニ行フコトメ防疫上實 $=$ 师要ナル事項ナリトス.

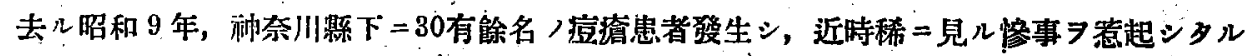

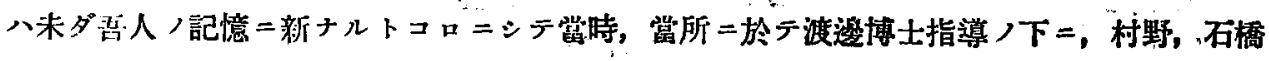
兩氏ハ之ガ詳細ナル檢查成繢

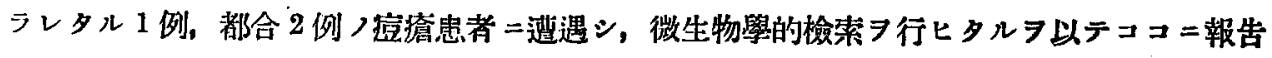
セントス. 


\begin{tabular}{|c|c|c|c|c|c|}
\hline 星 & 野 & 貫， & 和 & & \\
\hline
\end{tabular}

\section{第 1 童 检查事項並二檢查材料}

\section{第 । 第检查事項}

余等八 (1) Elementarkörperchen (Paschensche Körperehen); (2) Paulsches Phänomen, (3) Guarnierische Korperchen /3者=就丰筫驗 7 行ヒタリ.ソレガ詳細八村野, 石橋雨氏，

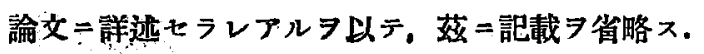

\section{第 2 简 检查、材 料}

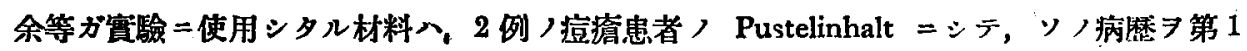

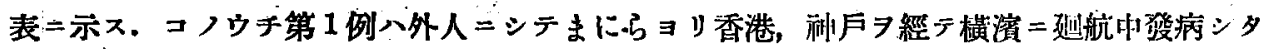
ルモノニシテ、第2例八墢病數白前支那ヨリ歸來七ルモノナリ．第3例ハぢふてりー二テ橫演

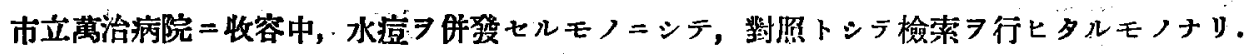

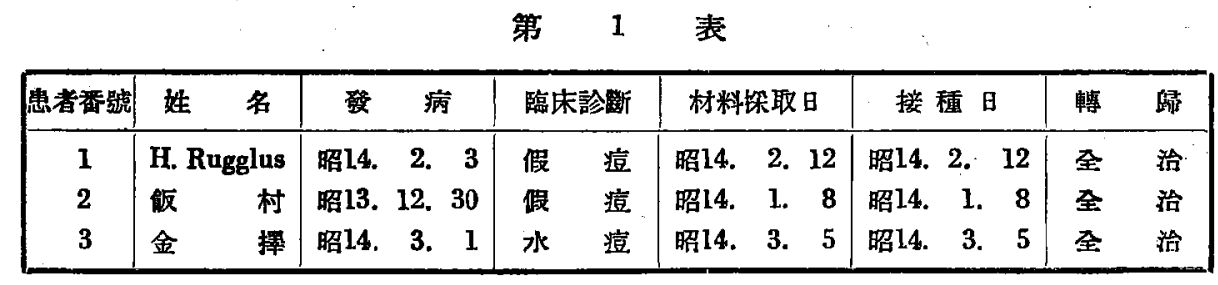

\section{第 2 童 检査成 樍}

(1) Elementarkörperchen oder Paschensche Körperchen. 清淨ナルおぶえくとぐらす

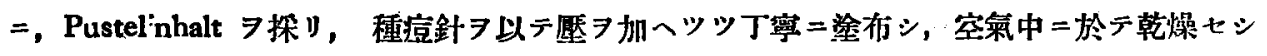

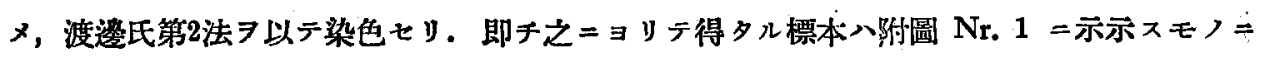

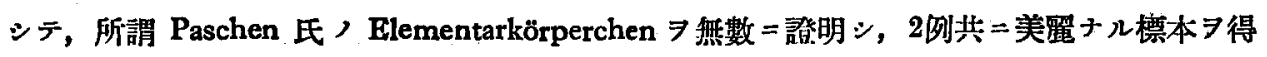

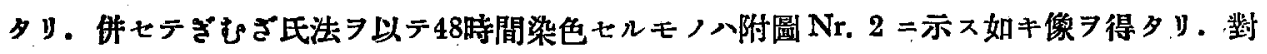
照トシテ試ミタル水撢患者材料二於テハ陰性二終レリ.

(2) Paulsches Phänomen 食監水

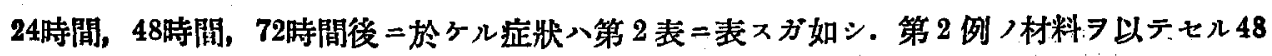
時間後二於ヶ几馈場像 7 附圖 Nr. 3 =示ス. 


\begin{tabular}{|c|c|c|c|c|c|c|}
\hline 㤟者 & 家鬼眼球 & 材 & 料 & 24 侍間 後 & 48 時 間 後 & 72 時 間 後 \\
\hline \multirow{2}{*}{1} & 右 & \multicolumn{2}{|c|}{ Pustelinhalt } & 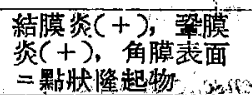 & 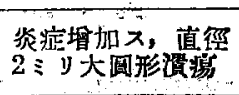 & 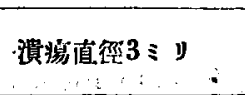 \\
\hline & 左 & " & $" 1$ & 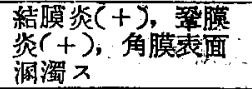 & 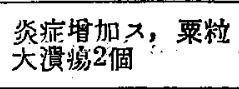 & 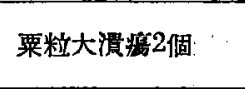 \\
\hline \multirow{2}{*}{2} & 右 & . & & 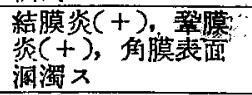 & 咨症罾加ス，默占狀 & 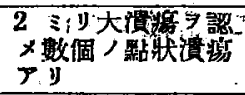 \\
\hline & 左 & " & "l & 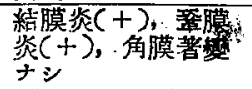 & $\begin{array}{l}\text { 炎遈增加源 } \\
\text { 將赸物 } 1 \text { 個 }\end{array}$ & 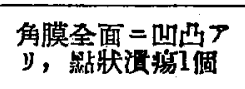 \\
\hline \multirow{2}{*}{3} & 吉 & " & " & 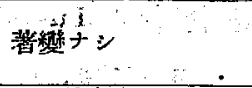 & 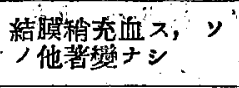 & 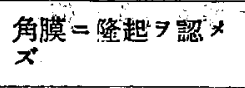 \\
\hline & 左: & \multicolumn{2}{|c|}{ Kruste } & 著䅗ナシ & 著鶖ナシ & 著禁ナシ \\
\hline
\end{tabular}

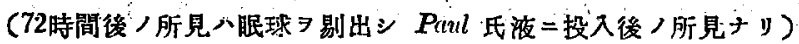

(3) Guarnierische Körperchen (G. K.) 渡櫋博士ハ好ンデ健康部卜久損部卜ノ境界二觀

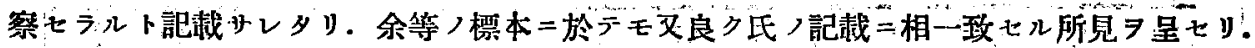

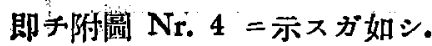

\section{結 論}

以上ノ檢查成績ヨリ余等ハ次ノ如キ結諭 7 述ベントス.

1) Elementarkörperchen，檢弥公材料探取後 1 時間以丙 $=$ ソ 成績 7 制定シ得ル早期診 斷方法+リ.

2) Paulsches Phänomen 八材料接種後 24 時間ニシデ䚋察シ得ル極メテ重要ナル診定方法 ナリ.

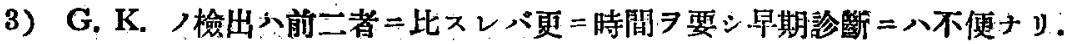

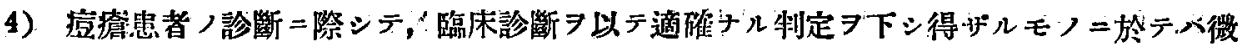
生物學的檢查ヨ行フベキモノトス.

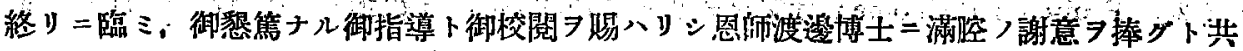

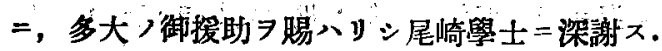

\section{主要引用書}

1) H. Watanabe, Beiträge zur Färbung der Paschenschen Körperchen (Elementarkörperchen). Zentralbl. f. Bakt. etc. Orig. 1930. Bd. 116.

2) E. Gildemeister und 


\section{星野 - 和田論交附圖}
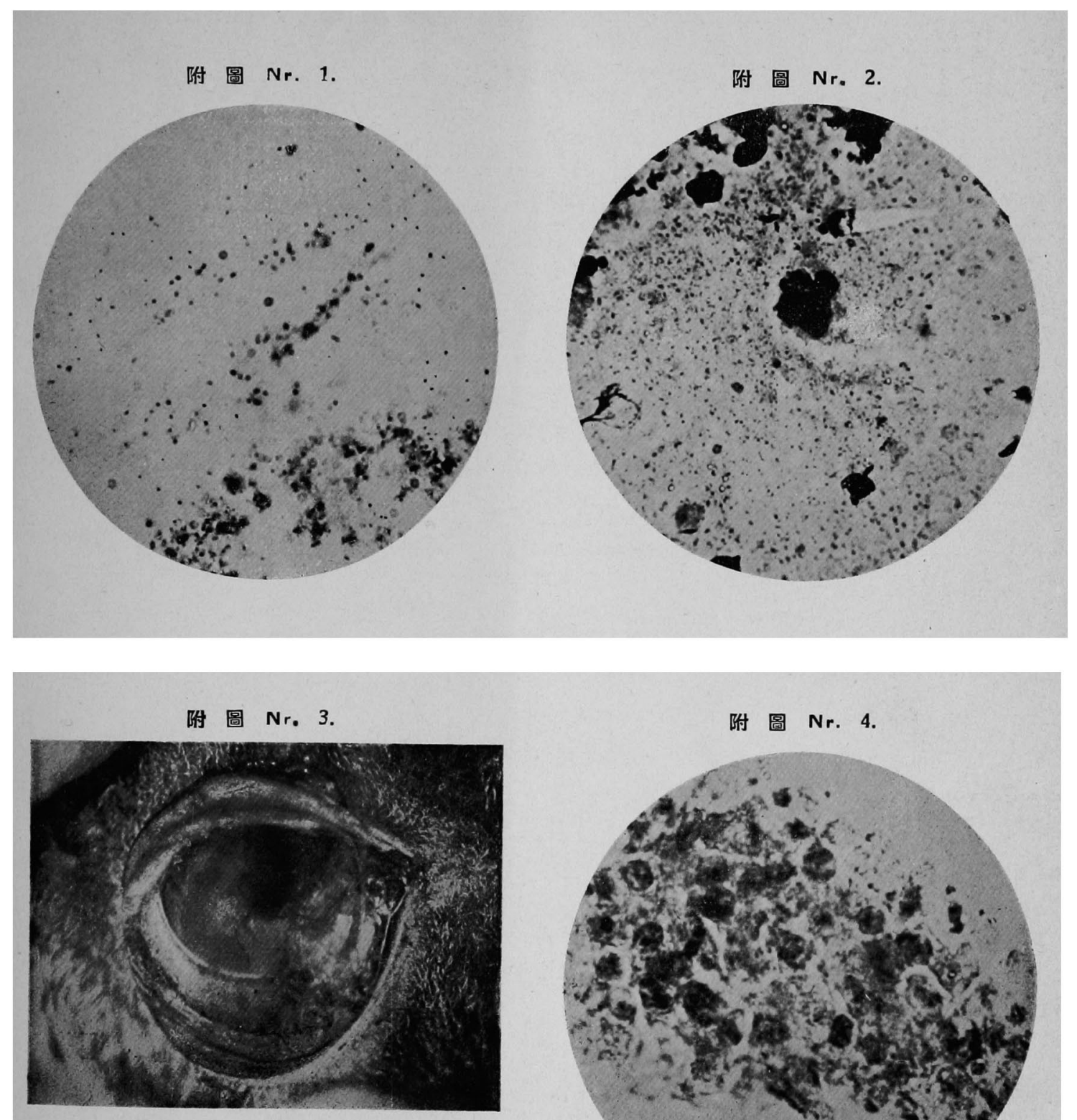

附 圖 Nr. 4.

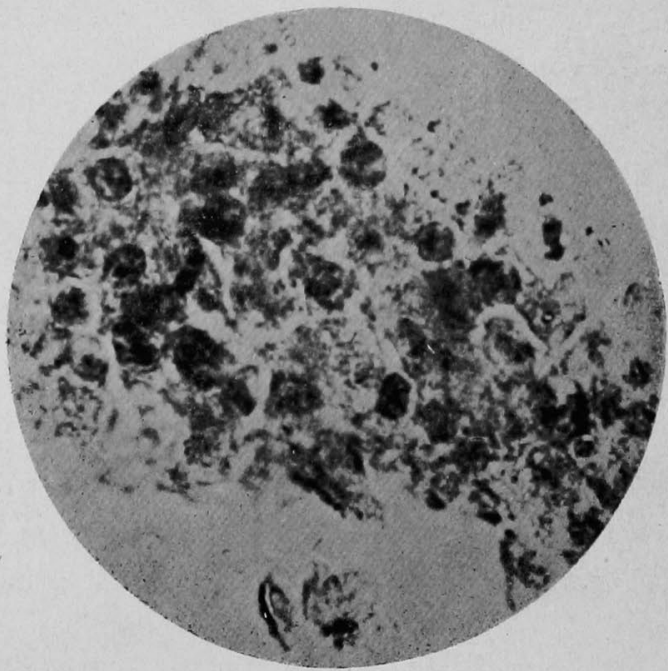


H. Watanabe, Zur Bestimmung kleinsler Mengen von Diphtherietoxin und Diphtherieantitoxin. Zentralbl. f. Bakt. ete. Orig 1930. Bd. 117.

3) H. Watanabe, Ueber Einschlusskörperchen bei Herpes simplex. Zentralbl. f. Bakt. etc. Orig. 1930. Bd. 116.

4) H. Watanabe; Ueber die Bildung unspezifischr Zelleinschlusse in der Kaninchenhornhaut. Zenträlbl. f. Bakt. etc. Orig. 1930. Bd. 119.

5) E. Paschen, Pocken, Handbuch der Pathogenen Mikroorgañismen Dritte; erweịterte Auflage, achter Band. 1930.

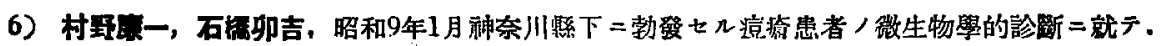
東京罯事新誌，第2870號，昭和9年。

\section{附 圆 解 說}

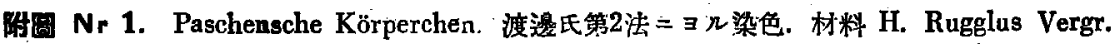
ok $4 \times 2 \mathrm{~mm}$.

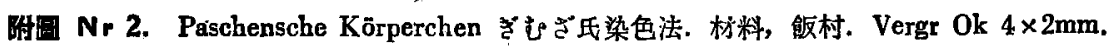

唯朋 Nr 3. Paulsches Phänomeh. 材料，饭村. 48時間後所見.

坿圆 Nr 4. Guarnierische Körperchen. Hornhautschnitt, 72 std. 材料, 饭村. Vergr Ok $4 \times 2 \mathrm{~mm}$. 